\title{
Pelatihan Pembuatan dan Penggunaan Alat Peraga Matematika dan IPA bagi Guru SD dan SMP di Desa Tanjung Saleh
}

\section{The Training in Making and Using of Mathematics and Science Teaching Aids for Elementary and Junior High School Teachers in Tanjung Saleh Village}

\author{
Syarifah Fadillah, Wahyudi, dan Nurhayati \\ Fakultas Pendidikan MIPA dan Teknologi, IKIP PGRI Pontianak, \\ Email: syffadillah@gmail.com
}

\begin{abstract}
Abstrak
Program Kemitraan Masyarakat (PKM) ini bertujuan untuk melatih guru matematika dan IPA SD dan SMP di sekolah mitra untuk membuat media pembelajaran berupa alat peraga sederhana dan menggunakannya dalam proses pembelajaran dengan menerapkan model pembelajaran berbasis scientific approach. Kegiatan pengabdian ini berbentuk pelatihan, simulasi, dan ujicoba alat peraga matematika dan IPA SD dan SMP. Langkah-langkah teknis dalam kegiatan ini adalah : pembuatan alat peraga beserta buku panduan penggunaannya tim PKM, pelatihan pembuatan alat peraga, simulasi dan ujicoba penggunaan alat peraga dalam pembelajaran matematika dan IPA SD dan SMP. Hasil dari PKM ini adalah : 1) peserta dapat membuat alat peraga sederhana, 2) peserta dapat menggunakan alat peraga dalam pembelajaran matematika dan IPA di kelas, dan 3) siswa senang belajar menggunakan alat peraga dan meningkatkan pemahaman siswa dalam pelajaran matematika dan IPA.
\end{abstract}

Kata kunci: PKM, Alat Peraga, Buku Panduan

\begin{abstract}
The Community Partnership Program (PKM) aims to train elementary and junior high school math and science teachers in partner schools to create learning media in the form of simple teaching aids and use them in the learning process by applying the model of scientific approach based learning. This PKM is in the form of training, simulations, and trials of mathematics and science teaching aids in the elementary and junior high school. The technical steps in this activity are: making teaching aids and guide book for using teaching aids from the PKM team, training in the making of teaching aids, simulations and testing the use of teaching aids in the learning of mathematics and science in elementary and junior high school. The results of this PKM are: 1) participants can make simple teaching aids, 2) participants can use teaching aids in learning mathematics and science in class, and 3) students enjoy learning to use teaching aids and improve students' understanding of mathematics and science.
\end{abstract}

Key words: PKM, Teaching Aids, Guide Book

\section{PENDAHULUAN}

Siswa Sekolah Dasar (SD) yang berumur antara tujuh sampai dengan duabelas tahun pada dasarnya perkembangan intelektualnya termasuk dalam tahap operasional kongkret, sebab berfikir logiknya didasarkan atas manipulasi fisik dari obyek-obyek (Piaget, J. 1972). Dengan kata lain penggunaan media (termasuk alat peraga) dalam pembelajaran matematika dan Ilmu Pengetahuan Alam (IPA) di SD memang diperlukan, karena sesuai dengan tahap berpikir siswa. Demikian pula dengan siswa Sekolah Menengah Pertama, walaupun telah memasuki tahap operasional formal, namun dalam pembelajaran di sekolah, siswa SMP masih memerlukan media pembelajaran untuk memahami materi dengan baik.

Selain itu yang paling penting adalah kedudukan alat peraga terkait dengan fungsi 
pedagogik yang merupakan salah satu upaya untuk mempertinggi proses interaksi guru dengan siswa di lingkungan belajarnya. Melalui alat peraga siswa dapat berperan aktif dalam pembelajaran. Proses interaksi akan terjalin antara siswa dengan guru dan juga antara siswa dengan siswa ketika mereka belajar dengan menggunakan alat peraga.

Pada sekolah di daerah terpencil, pemilihan media pembelajaran haruslah yang mudah diperoleh dan dapat digunakan dengan keterbatasan sarana yang dimiliki sekolah. Desa Tanjung Saleh merupakan desa terpencil yang belum terhubung dengan listrik (PLN) dari kecamatan atau kabupaten, sehingga sumber listrik dibangun secara mandiri oleh pemerintah di desa dan hanya hidup pada malam hari dan mati pada siang hari. Dengan kondisi ini maka tidak memungkinkan untuk menggunakan media pembelajaran yang menggunakan listrik.

Hasil wawancara dengan kepala sekolah SD Negeri 31 dan SMP Negeri 15 satu atap di desa Tanjung Saleh, diperoleh informasi bahwa guru yang mengajar di kedua sekolah satu atap tersebut kebanyakan guru honorer bukan Pegawai Negeri Sipil sehingga guruguru tersebut jarang mendapatkan pelatihanpelatihan dari Kementerian Pendidikan Nasional dalam rangka peningkatan kompetensi guru. Oleh karena itu, pada saat guru mengajar di dalam kelas kurang atau belum pernah menggunakan model pembelajaran berbasis scientific approach dan menggunakan media-media inovatif yang dapat mempermudah siswa dalam memahami materi pelajaran khususnya mata pelajaran Matematika dan IPA.

Beberapa fungsi alat peraga dalam pembelajaran Matematka, antara lain: untuk mewujudkan situasi belajar yang fleksibel dan efektif, bukan sekedar assesoris semata; dengan alat peraga terintegrasi kontent dan tujuan pembelajaran; memotivasi siswa menjadi senang belajar matematika, untuk mempercepat siswa dalam memahami materi matematika, sebagai jembatan untuk membuat siswa dalam berfikir secara abstrak; desain alat peraga fleksibel sehingga dapat dimanipulasi untuk digunakan secara berkelompok maupun secara individu (Djahir, et all. 2017).

Demikian pula dalam pembelajaran IPA. Penggunaan metode dan media pembelajaran tepat, menarik dan menyenangkan membuat siswa cenderung semakin giat belajar IPA. Dengan menggunakan alat peraga, siswa bekerja dengan alat peraga (hands-on exercises), yang melalui kegiatan tersebut, siswa mendapatkan peningkatan aspek mengingat, memahami, mengaplikasikan yang lebih tinggi (Anggoro, S. 2014). Sudarisman menyatakan bahwa melalui hands-on activities base on daily life membuat siswa merasakan belajar IPA lebih bervariasi, menyenangkan dan bermakna (Sudarisman, S. 2011).

Mengingat pentingnya penggunaan alat peraga dalam pembelajaran matematika dan IPA, maka hal ini menjadi dasar untuk mengadakan pelatihan pembuatan media pembelajaran berupa alat peraga sederhana untuk membantu guru matematika dan IPA di SD Negeri dan SMP Negeri 15 satu atap di desa Tanjung Saleh dalam melaksanakan proses belajar mengajar.

Setelah guru terampil dalam membuat alat peraga, kemudian guru matematika dan IPA di kedua sekolah tersebut dilatih untuk menggunakannya dalam proses pembelajaran dengan menerapkan model pembelajaran berbasis scientific approach.

\section{SOLUSI/TEKNOLOGI}

Kegiatan pengabdian ini merupakan rangkaian kegiatan dari Program Kemitraaan Masyarakat (PKM) Direktorat Riset dan Pengabdian Masyarakat (DRPM) Kementerian Riset, Teknologi dan Perguruan Tinggi (Ristekdikti). Kegiatan PKM ini meliputi ceramah, pelatihan, simulasi dan ujicoba alat peraga matematika dan IPA SD dan SMP. Secara rinci metode yang dapat diuraikan adalah sebagai berikut.

1. Pembuatan alat peraga matematika dan IPA SD dan SMP oleh tim PKM 
bersama mahasiswa. Alat peraga ini untuk diserahkan kepada sekilah mitra.

2. Pembuatan buku panduan pembuatan dan penggunaan alat peraga dalam pembelajaran.

3. Pelatihan pembuatan alat peraga sederhana matematika dan IPA SD dan SMP.

4. Simulasi penggunaan alat peraga matematika dan IPA SD dan SMP.

5. Ujicoba penggunaan alat peraga matematika dan IPA SD dan SMP oleh guru kelas SD dan guru matematika dan IPA SMP oleh empat orang guru model.

6. Evaluasi pelaksanaan kegiatan PKM.

7. Serah terima alat peraga matematika dan IPA kepada sekolah mitra.

\section{HASIL DAN DISKUSI}

Kegiatan pengabdian ini dilaksanakan pada tanggal 13 - 14 Agustus 2018 dan 7 - 8 September 2018 yang diikuti oleh guru kelas SD Negeri 31 Sungai Kakap dan guru matematika dan IPA SMP Negeri 15 Sungai Kakap. Kegiatan pengabdian ini merupakan rangkaian kegiatan dari PKM, yang diawali dengan komunikasi kepada kepala SD dan SMP di sekolah mitra. Kegiatan dilanjutkan dengan sosialisasi kegiatan PKM kepada guru-guru SD dan SMP. Kegiatan berikutnya adalah menyelenggaran seminar pemanfaatan alat peraga matematika dan IPA bagi guru SD dan SMP di desa Tanjung Saleh. Dalam seminar ini guru dijelaskan tentang kegunaan alat peraga matematika dan IPA guna menunjang proses pembelajaran berbasis scientific approach yang digunakan dalam kurikulum 2013.

Kegiatan berikutnya adalah membuat alat peraga matematika dan IPA untuk kedua sekolah mitra. Dalam kegiatan ini tim PKM dibantu oleh beberapa orang mahasiswa program studi Pendidikan Matematika dan Pendidikan Fisika IKIP PGRI Pontianak. Adapun alat peraga yang dibuat adalah:

1. Alat peraga matematika SD yaitu: (1) blok pecahan, (2) blok dienes, (3) garis bilangan, (4) papan berpaku, (5) segitiga ajaib, dan (6) kartu pecahan.

2. Alat peraga IPA SD yaitu (1) miniatur lingkungan sekolah, (2) foto clip sumber energi, (3) model lapisan bumi, (4) papan perubahan energi, thermometer sederhana, dan (6) model tata surya.

3. Alat peraga matematika SMP yaitu (1) kartu persamaan linier, (2) loncat katak, dan (3) kubus dan balok.

4. Alat peraga IPA SMP yaitu (1) media gerhana, (2) puzzle sistem pencernaan, dan (3) rangkaian seri dan paralel.

Tim PKM juga menyiapkan buku panduan penggunaan alat peraga matematika dan IPA untuk guru SD dan SMP. Buku panduan tersebut berisi tentang cara membuat alat peraga dan cara penggunaannya dalam pembelajaran. Buku panduan juga dilengkapi dengan Rencana Pelaksanaan Pembelajaran (RPP) dan Lembar Kerja Siswa (LKS) yang berbasis scientific approach sehingga akan memudahkan guru ketika menggunakan alat peraga tersebut dalam proses pembelajaran.

Kegiatan inti dari pengabdian ini adalah melatih guru untuk membuat alat peraga sederhana. Kegiatan ini dilaksanakan pada tanggal 13 Agustus 2018. Dalam kegiatan ini guru-guru SD dan SMP dilatih untuk membuat alat peraga matematika dan IPA dari bahan-bahan sederhana sehingga alat peraga tersebut dapat digunakan dalam kelompok-kelompok belajar siswa. Kegiatan tersebut dilanjutkan dengan simulasi penggunaan alat peraga dalam pembelajaran matematika dan IPA. Simulasi dilakukan oleh tim PKM yang bertindak sebagai guru, dan guru bertindak sebagai siswa..Kegiatan simulasi dilaksanakan tanggal 14 Agustus 2018 .

Selanjutnya kegiatan pengabdian dilanjutkan dengan ujicoba penggunaan alat peraga matematika dan IPA di beberapa kelas di SD dan SMP, di sekolah mitra. Kegiatan dilakukan pada tanggal 7 September 2018. Kegiatan pengabdian 
diakhiri dengan evaluasi pelaksanaan kegiatan PKM dan serah terima alat peraga kepada sekolah mitra pada tanggal 8 September 2018.

Hasil evaluasi pada tahap pelatihan pembuatan alat peraga, diperoleh hal-hal sebagai berikut. 1) pendampingan selama proses pelatihan oleh tim PKM berjalan dengan baik; 2) guru di sekolah mitra antusias dalam membuat alat peraga dan aktif bertanya jika kurang jelas; 3) guru di sekolah mitra tertarik untuk mengembangkan media pembelajaran matematika dan IPA. Hasil evaluasi pada tahap simulasi dan ujicoba penggunaan alat peraga dalam pembelajaran, diperoleh halhal sebagai berikut. 1) simulasi penggunaan alat peraga matematika dan IPA oleh tim PKM berjalan dengan baik; 2) guru di sekolah mitra antusias mengikuti kegiatan simulasi dan aktif bertanya jika kurang jelas; 3) guru di sekolah mitra antusias dalam mengujicobakan alat peraga dalam pembelajaran matematika dan IPA di kelas mereka, 4) siswa di kelas ujicoba pembelajaran, antusias dan senang mengikuti pembelajaran dengan menggunakan alat peraga.

Dalam proses belajar, pengalaman belajar siswa sangatlah penting. Pengalaman tersebut akan membentuk suatu pemahaman apabila ditunjang dengan alat bantu belajar, yang berfungsi mengkonkretkan materimateri yang bersifat abstrak. Dengan demikian alat bantu belajar atau biasa disebut alat peraga akan berfungsi dengan baik apabila alat peraga tersebut dapat memberikan pengalaman belajar yang bermakna, mengaktifkan dan menyenangkan siswa. Dapat dikatakan bahwa alat peraga memiliki peranan sangat besar bagi guru yaitu untuk menyampaikan materi pelajaran kepada siswanya (Sukayati dan Suharjana, A. 2009).

Alat peraga dalam matematika dapat digunakan sebagai jembatan bagi siswa untuk berpikir abstrak. Hal ini dikarenakan obyek dalam pembelajaran matematika yang berupa fakta, konsep, prinsip dan skill/ keterampilan bersifat abstrak dan tidak dapat diamati dengan pancaindera. Untuk mengatasi hal tersebut, maka dalam mempelajari suatu obyek dalam pembelajaran matematika diperlukan pengalaman melalui benda-benda nyata (konkret) (Widyantini, T.H dan Sigit, T.G. 2010).

Alat peraga dalam IPA dapat bermanfaat untuk menunjukkan gejala IPA yang sesungguhnya secara langsung kepada siswa, sehingga dengan menggunakan alat peraga tersebut pembelajaran IPA menjadi lebih bermakna bagi siswa Mohammad Amin, dkk. 2013).

Berdasarkan pengamatan, tanya jawab dan diskusi dengan guru di sekolah mitra, baik dalam kegiatan pelatihan, simulasi, ujicoba dan evaluasi, tampak bahwa guru-guru bersemangat mengikuti setiap kegiatan yang dilaksanakan oleh tim PKM. Beberapa peserta memandang bahwa kegiatan seperti ini perlu diselenggarakan dan waktu pelaksanaan ditambah, agar lebih banyak lagi alat peraga yang dipraktekkan pembuatan dan penggunaannya dalam pembelajaran matematika dan IPA di kelas. Guru di sekolah mitra juga merasa mendapatkan manfaat dengan adanya alat peraga yang diberikan di sekolah beserta panduan penggunaannya, sehingga mereka dapat menggunakan alat peraga tersebut dalam pembelajaran yang mereka lakukan di kelas.

\section{KESIMPULAN}

Pelatihan pembuatan alat peraga matematika dan IPA dan penggunaannya dalam pembelajaran di SD dan SMP satu atap Desa Tanjung Saleh berjalan dengan baik. Guru di kedua sekolah mitra antusias dalam mengikuti rangkaian kegiatan PKM. Mereka tertarik untuk membuat alat peraga sederhana dan mencoba menggunakannya dalam pembelajaran matematika dan IPA di sekolah mereka. Mereka mendapatkan pengetahuan baru tentang bagaimana menggunakan alat peraga dalam pembelajaran yang dapat membuat pembelajaran mereka menjadi menarik dan 
menyenangkan sehingga dapat meningkatkan minat dan pemahaman siswa dalam belajar matematika dan IPA

Pengabdian masyarakat ini masih dapat dilanjutkan terutama dalam hal pembuatan dan penggunaan alat peraga dalam pembelajaran matematika dan IPA di sekolah sehingga dapat membantu dan mempermudah siswa dalam memahami pelajaran mtematika dan IPA.

\section{UCAPAN TERIMA KASIH}

Tim PKM mengucapkan terima kasih kepada Fakultas Matematika dan Ilmu Pengetahuan Alam yang telah mendukung pelaksanaan PKM melalui dana DIPA Unesa anggaran tahun 2018.

\section{PUSTAKA}

Piaget, J. (1972). The Psychology of the Child. New York: Basic Books B.

Djahir, et all. (2017). Alat Peraga dalam Geometri Ruang (Sumber Belajar Penunjang PLPG 2017, Mata Pelajaran/ Paket Keahlian Matematika). Jakarta: Direktorat Jenderal Guru dan Tenaga Kependidikan, Kementerian Pendidikan dan Kebudayaan
Anggoro, S. (2014). Analisis Perbandingan Sikap Belajar dan Penguasaan Konsep IPA menggunakan Strategi Joyful Learning di Kelas IV SD Kota Bandung. Thesis Universitas Pendidikan Indonesia. Bandung. Tidak dipublikasikan.

Sudarisman, S. (2011). Pembelajaran Sains Pada Pendidikan Anak Usia Dini Melalui Hands On Activities Based On Daily Life untuk Anak. Prosiding Seminar Internasional ke-3 dan Workshop Pedagogik Praktis yang Berkualitas (p. 320-335. Bandung: Universitas Pendidikan Indonesia.

Sukayati dan Suharjana, A. (2009). Pemanfaatan Alat Peraga Matematika dalam Pembelajaran di SD. Yogyakarta: Direktorat Jenderal Peningkatan Mutu Pendidik dan Tenaga Kependidikan Departemen Pendidikan Nasional.

Widyantini, T.H dan Sigit, T.G. (2010). Pemanfaatan Alat Peraga dalam Pembelajaran Matematika SMP. Yogyakarta: Direktorat Jenderal Pendidikan Dasar Dan Menengah Departemen Pendidikan Nasional.

Mohammad Amin, dkk. (2013). Bahan Pelatihan Pengelola Laboratorium Sekolah Menengah Pertama. Modul. Jakarta: Kemendikbud 